\title{
CO-FIRING OF BIOMASS WITH GAS FUEL IN LOW-POWER BOILERS
}

\author{
Artur Kraszkiewicz ${ }^{1}$, Pawel Sobczak ${ }^{1}$, Francesco Santoro ${ }^{2}$, \\ Alexandros Sotirios Anifantis ${ }^{2}$, Simone Pascuzzi ${ }^{2}$ \\ ${ }^{1}$ University of Life Sciences in Lublin, Poland; ${ }^{2}$ University of Bari Aldo Moro, Italy \\ artur.kraszkiewicz@up.lublin.pl,pawel.sobczak@up.lublin.pl, francesco.santoro@uniba.it, \\ alexandrossotirios.anifantis@uniba.it,simone.pascuzzi@uniba.it
}

\begin{abstract}
Combustion is a complex process. It consists of many physical and chemical processes of thermal decomposition and fuel combustion taking place in a specific space and time. This paper examines the evaluation of the process of combustion pellets and briquettes made from oat straw in a low-power grate boiler $10 \mathrm{~kW}$, which was carried out in two variants: without modification of the combustion chamber and with its modification. In the boiler processing, an element limiting the combustion chamber was used; it was made of steel strips with dimensions (length $\times$ width $\times$ thickness) of $100 \times 3 \times 1 \mathrm{~mm}$ attached radially at one end to a steel core $50 \mathrm{~mm}$ long, under which, using a mixture of butane and propane in a 70:30 ratio, a secondary combustion zone was created. Combustion of pellets without modification of the combustion chamber was characterized by increased dynamics, which was indicated by higher combustion rate, higher flue gas temperature and lower air excess. At the same time, modification of the combustion chamber applied in the scope of these parameters contributed to reduction of the combustion rate and flue gas temperature, while reducing the air excess that was absorbed by combustion of the gaseous fuel. Emission of pollutants with combustion of pellets and briquettes without modification of the combustion chamber was characterized by similar values in the CO and NO range, only for briquettes, the $\mathrm{SO}_{2}$ emission was more than twice as high. However, by modifying the combustion chamber along with the use of additional gaseous fuel, a reduction of CO by $15 \%$ was achieved. Higher NO and $\mathrm{SO}_{2}$ emissions were observed. It would be expedient to conduct research to a greater extent related to optimization of $\mathrm{CO}, \mathrm{NO}$ and $\mathrm{SO}_{2}$ emissions using other types of herbaceous biomass.
\end{abstract}

Keywords: combustion, emission, herbaceous biomass.

\section{Introduction}

In recent years, Polish rural areas have undergone major structural, spatial and economic changes. Currently, shaping and development of these areas cannot exist without taking into account the protection of natural resources. Therefore, there are large needs in the field of environmental engineering and sustainable development of these areas $[1 ; 2]$. In this respect, in many countries, the research is conducted that focuses on: the quality of agricultural raw materials [3-8], new technologies in the field of agriculture using modeling techniques [9-11], safety of technical facilities, animals and the population [12-13], as well as in the field of energy, paying attention to renewable energy sources [14-16].

Research on the problem of the quality of the combustion process in low power heating devices powered by solid fuels is undertaken because of significant impact of such devices on air quality. In countries such as Poland, the share of individual heating is relatively significant. The popularity of such a solution results from the poorly developed gas fuel distribution system infrastructure and much lower solid fuel prices. At the same time, many thermal installations, especially the old ones, are supplied with coal [17-19].

Combustion is a complex process. It consists of many physical and chemical processes of thermal decomposition and fuel combustion, taking place in a specific space and time. The quality of the combustion processes in low-power boilers to about $20-25 \mathrm{~kW}$ results directly from the thermodynamic parameters of the combustion process in the boiler and construction of the combustion chamber.

Therefore, the analysis of the combustion process requires knowledge of the properties of fuels and their impact on its course. Less carbonization of biomass fuels, apart from affecting the technical characteristics of fuels, e.g. on calorific value, also determines the course of the combustion process in its individual phases [20-22].

Considering the phases of this process, we distinguish the following ones: drying, degassing, coke gasification and slag cooling processes, successively on the grate. It is important that after charging boilers into the combustion chamber a transient state arises, characterized by increased emission dynamics, which gradually goes into steady state until the flame disappears and the coking residue is 
burnt. The disadvantage of grate boilers, especially those powered by biomass, is the free flow of volatile substances through the heat exchanger towards the chimney. This results in increased hydrocarbon emissions and thus reduction in the efficiency of the combustion process $[19 ; 23]$.

Therefore, this research was carried out to assess the process of combustion pellets and briquettes from oat straw in a low-power grate boiler $10 \mathrm{~kW}$, which was carried out in two variants: without modification of the combustion chamber and with its modification.

\section{Materials and methods}

Oat straw was selected for the research as a waste material that is widely available in connection with the production of oats. This biomass came from a farm located in Lublin province. Representative samples weighing $25 \mathrm{~kg}$ were taken from the field, then ground with a $\mathrm{H}-111$ hammer mill with $10 \mathrm{~mm}$ sieves. Then it was agglomerated to pellets and briquettes. Pelleting was carried out in a granulator using an $8 \mathrm{~mm}$ matrix and briquetting in a hydraulic briquetting machine with a sleeve diameter of $50 \mathrm{~mm}$.

When determining the physical and chemical properties of raw materials and produced biofuels, the following methods were used (measurements were carried out in triplicate):

- geometrical features (diameter and length) - according to EN ISO 17829: 2016-02 [24];

- moisture - weight method according to EN ISO 18134-3: 2016 [25];

- density - calculated on the basis of geometrical features in the drawn samples and the mass of biofuel portions, using the following formula:

$$
\rho_{w}=\frac{4 \cdot 10^{6} \cdot m}{\Pi \cdot d^{2} \cdot l}
$$

where $\rho_{w}$-density of briquettes or pellets, $\mathrm{kg} \cdot \mathrm{m}^{-3}$,

$m$ - mass of the fuel portion, briquettes or pellets, $\mathrm{g}$,

$d$ - average diameter of briquettes or pellets, $\mathrm{mm}$,

$l$ - sum of the length of briquettes or pellets in a fuel portion, $\mathrm{mm}$.

- carbon, hydrogen, nitrogen - determination according to EN ISO 16948: 2015 [26];

- sulfur - determination according to EN ISO 16994: 2015 [27];

- part of volatile components - determination according to EN ISO 18123: 2016 [28];

- net calorific value - calculation after determining the calorific value according to EN ISO 18125: 2017 [29];

- ash - according to the EN ISO 18122: 2016 standard [30].

The fuel collected for testing in portions of $1 \mathrm{~kg}$ was burned in a grate heating device, fueled periodically. Two combustion variants were adopted. The first one without modification of the combustion chamber, while in the second one at the top of the combustion chamber, a chamber limiting element made of steel sheet strips with dimensions (length $\times$ width $\times$ thickness) $100 \times 3 \times 1 \mathrm{~mm}$ attached radially to one end with a $50 \mathrm{~mm}$ long steel core was applied, under which a secondary combustion zone was created with a mixture of butane and propane in a ratio of 70:30 (Figure 1). The purpose of this zone was to additionally burn off volatile organic compounds, such as $\mathrm{CO}$. Gas supply and flame were active for the initial $300 \mathrm{~s}$ of combustion the fuel portion.

Process timing, determinations of flue gas composition and temperature measurements were carried out continuously, i.e. from the moment of ignition to the time the reaction expired, for which the flue gas temperature drop to $120{ }^{\circ} \mathrm{C}$ was assumed. Flue gas was taken from the chimney. The measuring probe was connected to an exhaust gas dryer, from which the exhaust gas went to the exhaust gas analyzer. During the tests, a portable exhaust gas analyzer based on infrared sensors (NDIR) was used for the following gases: $\mathrm{CO}, \mathrm{CO}_{2}, \mathrm{NO}, \mathrm{SO}_{2}$ and electrochemical $-\mathrm{O}_{2}$. The temperature was measured using a K-type thermocouple, which was located in the exhaust gas sampling probe. The results were automatically recorded in the analyzer database every $2 \mathrm{~s}$, with the simultaneous recording of the data acquisition time. 
a)

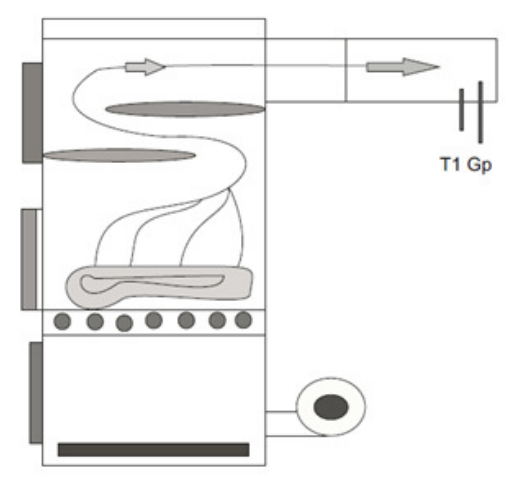

b)

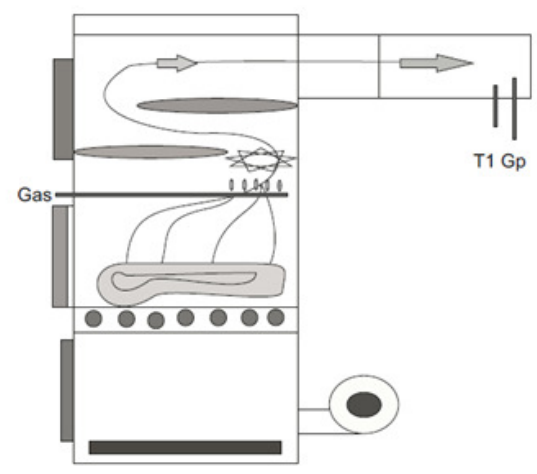

Fig. 1. Diagram of the test stand (combustion chamber): a) - before modification; b) - after modification; Gas - gas fuel fed to the combustion chamber, T1 - temperature measurement in the chimney, Gp - flue gas collection

\section{Results and discussion}

The average values of the results obtained (from three replicates) characterizing the raw material used and the biofuels made are presented in Tables 1 and 2.

Technical and chemical properties of biomass of oat straw

Table 1

\begin{tabular}{|l|c|c|c|}
\hline \multicolumn{1}{|c|}{ Parameter } & Symbol & Unit & Oat straw \\
\hline Total moisture & $W_{t}^{r}$ & $\%$ & $10.833 \pm 0.016$ \\
\hline Volatile meter & $V^{d}$ & $\%$ & $73.330 \pm 0.102$ \\
\hline Net calorific value & $Q_{i}^{r}$ & $\mathrm{MJ} \cdot \mathrm{kg}^{-1}$ & $15.475 \pm 0.031$ \\
\hline Ash & $A^{d}$ & $\%$ & $6.455 \pm 0.125$ \\
\hline \multirow{4}{*}{$\begin{array}{l}\text { Elemental } \\
\text { composition }\end{array}$} & $C^{d}$ & $\%$ & $43.670 \pm 0.286$ \\
\cline { 2 - 4 } & $H^{d}$ & $\%$ & $5.223 \pm 0.039$ \\
\cline { 2 - 4 } & $N^{d}$ & $\%$ & $0.440 \pm 0.052$ \\
\cline { 2 - 4 } & $S^{d}$ & $\%$ & $0.007 \pm 0.002$ \\
\hline
\end{tabular}

Physical properties of biofuels made of oat straw

\begin{tabular}{|l|c|c|c|c|}
\hline \multicolumn{1}{|c|}{ Parameter } & Symbol & Unit & Pellets & Briquettes \\
\hline Length & $L$ & $\mathrm{~mm}$ & $34 \pm 0.5$ & $29 \pm 0.5$ \\
\hline Diameter & $D$ & $\mathrm{~mm}$ & $8 \pm 0.5$ & $52 \pm 0.5$ \\
\hline Density & - & $\mathrm{kg} \cdot \mathrm{m}^{-3}$ & $1016 \pm 12$ & $858 \pm 11$ \\
\hline Mechanical durability & $D U$ & $\%$ & $98.17 \pm 0.25$ & $97.57 \pm 0.21$ \\
\hline
\end{tabular}

The oat straw used during the tests was characterized by comparable technical and chemical characteristics with the results of the tests presented by Górnicki et al. [31]. Particularly noteworthy here is the content of volatiles at the level of $73 \%$, a relatively high calorific value comparable to other types of straw $15.47 \mathrm{MJ} \cdot \mathrm{kg}^{-1}$ and quite high ash content at the level of $6.5 \%$ (Table 1). The improvement of geometrical parameters of this biomass is obtained in the process of its compaction. The pellets and briquettes produced during the tests in the range of considered features were characterized by desirable geometrical features, thus meeting the assumptions of relevant quality standards $[20 ; 32]$.

The recorded parameters of the process of combustion pellets and briquettes are presented in Table 3. Combustion tests of fuels selected for the study were conducted under comparable conditions when fed with air stream from below under the grate, with an average rate of $2.5 \mathrm{~m} \cdot \mathrm{s}^{-1}$. During the tests, the combustion rate for pellets was about $30 \%$ higher than for briquettes and amounted to $4.36 \mathrm{~kg} \cdot \mathrm{h}^{-1}$, while for briquettes this parameter was about $3 \mathrm{~kg} \cdot \mathrm{h}^{-1}$. 
Parameters of the combustion process

\begin{tabular}{|c|c|c|c|c|}
\hline \multicolumn{2}{|c|}{ Combustion system } & $\begin{array}{c}\text { Combustion } \\
\text { rate, } \mathbf{k g}^{-\mathbf{1}} \mathbf{h}^{\mathbf{1}}\end{array}$ & $\begin{array}{c}\text { Air excess } \\
\text { coefficient }\end{array}$ & $\begin{array}{c}\text { Exhaust gas } \\
\text { temperature, }{ }^{\mathbf{o}} \mathbf{C}\end{array}$ \\
\hline $\begin{array}{c}\text { Pellets combustion } \\
\text { made of oat straw }\end{array}$ & without gas fuel & $4.36 \pm 0.10$ & $5.73 \pm 3.13$ & $260 \pm 112$ \\
\cline { 2 - 5 } & with gas fuel & $4.20 \pm 0.08$ & $5.53 \pm 3.22$ & $207 \pm 70$ \\
\hline $\begin{array}{c}\text { Briquettes combustion } \\
\text { made of oat straw }\end{array}$ & without gas fuel & $3.10 \pm 0.07$ & $5.98 \pm 2.19$ & $174 \pm 32$ \\
\cline { 2 - 5 } & with gas fuel & $2.68 \pm 0.07$ & $5.68 \pm 1.99$ & $163 \pm 38$ \\
\hline
\end{tabular}

Differences between fuel grades are also marked for the value of the air excess coefficient. Due to the constant air supply from the fan, during combustion of pellets, the air excess averaged to 5.5 (minimum about 2.5), while for briquettes - 6 (minimum about 3.5), but for pellets, larger fluctuations of this parameter were recorded, indicating the dynamics of combustion of this fuel. The modification of the boiler contributed to the reduction of the combustion rate and the air excess slightly decreased, obtaining in the combustion stabilized period the values close to those recommended in literature [19;23]. Differences related to the type of assortment and the combustion system were also reflected in the flue gas temperature indications, which for pellets was $260^{\circ} \mathrm{C}$ and $207^{\circ} \mathrm{C}$ on average without and with boiler modification, whereas for briquettes, it was $163{ }^{\circ} \mathrm{C}$ and $174{ }^{\circ} \mathrm{C}$ (Table 3). The applied modification of the combustion chamber (when a steel element was used together with gas fuel) in the scope of these parameters contributed to the reduction of the combustion rate and temperature of the flue gas in the chimney, while reducing the air excess that was absorbed by the combustion of the gaseous fuel. The content in exhaust gases as well as $\mathrm{CO}, \mathrm{NO}, \mathrm{SO}_{2}$, and $\mathrm{CO}_{2}$ emission factors are presented in Table 4.

Table 4

Emissions $\mathrm{CO}, \mathrm{NO}, \mathrm{SO}_{2}, \mathrm{CO}_{2}$ of the exhaust during combustion of oat straw without and with gas fuel

\begin{tabular}{|c|c|c|c|c|c|c|c|c|}
\hline $\begin{array}{c}\text { Combustion } \\
\text { system }\end{array}$ & Parameters & $\begin{array}{l}\text { CO, } \\
\text { ppm }\end{array}$ & $\begin{array}{c}\mathrm{CO}, \\
\mathrm{mg} \cdot \mathrm{m}^{-3} \\
\text { at } 10 \% \\
\mathrm{O}_{2}\end{array}$ & $\begin{array}{l}\text { NO, } \\
\text { ppm }\end{array}$ & $\begin{array}{c}\mathrm{NO}, \\
\mathrm{mg} \cdot \mathrm{m}^{-3} \\
\text { at } 10 \% \\
\mathrm{O}_{2}\end{array}$ & $\begin{array}{l}\mathrm{SO}_{2} \\
\mathrm{ppm}\end{array}$ & $\begin{array}{c}\mathrm{SO}_{2,} \\
\mathrm{mg}^{-3} \mathrm{~m}^{-3} \\
\text { at } \\
10 \% \\
\mathrm{O}_{2}\end{array}$ & $\underset{\%}{\mathrm{CO}_{2}}$ \\
\hline \multirow{4}{*}{$\begin{array}{l}\text { Pellets } \\
\text { without gas } \\
\text { fuel }\end{array}$} & maximum & 11240 & 88929 & 272 & 1209 & 113 & 2045 & 7.86 \\
\hline & average & 4191 & 18829 & 118 & 421 & 20 & 235 & 3.75 \\
\hline & kurto & & 7.13 & -0.45 & 14.61 & 13.23 & 11.06 & -0.75 \\
\hline & skewn & 0.70 & 2.27 & 0.21 & 3.36 & 3.28 & 3.24 & 0.16 \\
\hline \multirow{4}{*}{$\begin{array}{l}\text { Pellets with } \\
\text { gas fuel }\end{array}$} & maximum & 11160 & 57382 & 358 & 1787 & 290 & 2968 & 7.60 \\
\hline & average & 4165 & 16033 & 201 & 616 & 72 & 623 & 4.61 \\
\hline & kurtosis & 1.28 & 0.27 & 0.42 & 5.54 & 6.31 & 2.69 & -0.72 \\
\hline & skewness coefficient & 1.32 & 1.31 & -0.64 & 2.48 & 2.66 & 1.93 & -0.41 \\
\hline \multirow{4}{*}{$\begin{array}{l}\text { Briquettes } \\
\text { without gas } \\
\text { fuel }\end{array}$} & maximum & 6770 & 43923 & 145 & 1147 & 124 & 1960 & 5.41 \\
\hline & average & 4592 & 17431 & 118 & 463 & 76 & 678 & 3.74 \\
\hline & kurtos & 1.98 & 1.64 & 2.35 & 3.70 & -0.12 & 1.30 & -0.01 \\
\hline & skewnes & -0.71 & 1.37 & -1.36 & 1.70 & 0.45 & 1.32 & -0.45 \\
\hline \multirow{4}{*}{$\begin{array}{l}\text { Briquettes } \\
\text { with gas } \\
\text { fuel }\end{array}$} & maximum & 3733 & 37385 & 105 & 1260 & 75 & 1972 & 3.4 \\
\hline & average & 2257 & 16588 & 66 & 489 & 48 & 799 & 1.94 \\
\hline & kurtosis & 0.34 & 1.44 & -0.20 & 9.21 & 0.23 & 3.32 & -0.33 \\
\hline & skewness coefficient & -0.49 & 0.88 & -0.51 & 1.69 & -0.28 & 1.30 & 0.05 \\
\hline
\end{tabular}

Under the test conditions, pellet combustion occurred most rapidly with significant $\mathrm{CO}, \mathrm{NO}$ and $\mathrm{SO}_{2}$ emissions. At the same time, the use of an additional flame zone resulted in $15 \%$ reduction in the average value of emitted $\mathrm{CO}$ calculated as normal conditions at $10 \% \mathrm{O}_{2}$, but it resulted in an increase of over $100 \%$ in $\mathrm{NO}$ and $\mathrm{SO}_{2}$ emissions. However, $\mathrm{NO}$ emission during pellet combustion in the second variant probably increases according to the Zeldovich mechanism. During the combustion of briquettes in the first adopted variant of combustion $\mathrm{CO}$, NO emissions were comparable to the 
emission of these compounds during pellet combustion, while the $\mathrm{SO}_{2}$ emission was much higher. However, in the second variant with the modification of the combustion chamber, the same reduction by $15 \%$ in the $\mathrm{CO}$ emission factor was achieved, also observing higher $\mathrm{SO}_{2}$ emission with briquette combustion (Table 4). The values obtained in the first variant of combustion tests were comparable with the data presented by other researchers analyzing the emission of solid biofuels in the form of pellets and briquettes [18-20;33]. However, it is puzzling, what needs verification during testing with other fuels, why more $\mathrm{SO}_{2}$ emissions arise.

\section{Conclusions}

1. Combustion of pellets under the test conditions during the first variant without modification of the combustion chamber was characterized by increased dynamics, which was indicated by: higher combustion rate, higher flue gas temperature and lower air excess. At the same time, modification of the combustion chamber applied in the scope of these parameters contributed to reduction of the combustion rate and flue gas temperature, while reducing the air excess that was absorbed by the combustion of gaseous fuel.

2. Emission of pollutants with combustion pellets and briquettes without modification of the combustion chamber was characterized by similar emissions in the $\mathrm{CO}$ and NO range and more than twice as much $\mathrm{SO}_{2}$ emissions for briquettes. However, by modifying the combustion chamber along with the use of additional gaseous fuel, $\mathrm{CO}$ reduction of $15 \%$ was achieved. Higher $\mathrm{NO}$ and $\mathrm{SO}_{2}$ emissions were observed.

3. It would be expedient to conduct research to a greater extent related to optimization of $\mathrm{CO}, \mathrm{NO}$ and $\mathrm{SO}_{2}$ emissions using other types of herbaceous biomass.

\section{References}

[1] Żmija D. Sustainable development of agriculture and rural areas in Poland. Economic policy at a time of transformation and crisis. Studia Ekonomiczne Uniwersytetu Ekonomicznego w Katowicach 2014, 166, pp. 149-158.

[2] Pijanowski Z. Kształtowanie i rozwój obszarów wiejskich w aspekcie inżynierii środowiska (Shaping and development of rural areas in the aspect of environmental engineering). Czasopismo Inżynierii Lądowej, Środowiska i Architektury 2014, z. 61, nr 1, pp. 183-199. (In Polish)

[3] Kozak-Kalita M., Sobczak P., Zawiślak K., Mazur J., Panasiewicz M., Żukiewicz-Sobczak W. Influence of uv-c radiation on the microbiological purity in selected species of herbs. Health Problems of Civilization, 2018, vol. 12(4), pp. 285-290, DOI: 10.5114/hpc.2018.77838

[4] Żukiewicz-Sobczak W., Cholewa G., Sobczak P., Zagórski J., Wojtyła-Buciora P. Health risks associated with exposure to fungi. Agriculture and Agricultural Science Procedia. 7th International Scientific Symposium on Farm machinery and Processes Management in Sustainable Agriculture, Gembloux, BELGIUM, NOV 25-27, 2015, vol. 7, pp. 313-317, DOI: 10.1016/j.aaspro.2015.12.053

[5] Przywara A., Kachel M., Koszel M., Leszczyński N., Kraszkiewicz A., Anifantis A. S. The influence of digestate on the static strength of spring rapeseeds (Brassica napus var. arvensis). Sustainability, vol. 11(7), 2133, 2019.

[6] Przywara A., Kachel-Jakubowska M., Kraszkiewicz A., Koszel M. Comparision of physicochemical parameters of rape seeds applying the infrared spectroscopy method. W: IX International Scientific Symposium Farm machinery and processes management in sustainable agriculture : Symposium Proceedings, Lublin. 2017, pp. 324-329.

[7] Panasiewicz M., Mazur J., Sobczak P., Zawiślak K., Kraśnicka K., Kupryaniuk K. The chemical composition of powdered pumpkin pulp and its application for food purposes. Przemysł Chemiczny, 2018, vol. 97(5), pp. 758-761, DOI: 10.15199/62.2018.5.21

[8] Nadulski R. Masłowski, A.; Mazurek A.; Sobczak P.; Szmigielski M.; Żukiewicz-Sobczak W.; Niedziółka I.; Mazur J. Vitamin C and lutein content of northern highbush blueberry (Vaccinium corymbosum L.) juice processed using freezing and thawing. Journal of Food Measurement and Characterization. 2019, Vol. 13(4), pp. 2521-2528, DOI: 10.1007/s11694-019-00172-x

[9] Anifantis A.S., Camposeo S., Vivaldi G.A., Santoro F., Pascuzzi S. Comparison of UAV photogrammetry and 3D modeling techniques with other currently used methods for estimation of 
the tree row volume of a super-high-density olive orchard. Agriculture (Switzerland), vol. 9(11), 2019, 233.

[10] Bulgakov V., Pascuzzi S., Santoro F., Anifantis A.S. Mathematical Model of the Plane-Parallel Movement of the Self-Propelled Root-Harvesting Machine. Sustainability Volume 10(10), 2018, 378 - DOI: 10.3390/su10103614

[11]Bulgakov V., Pascuzzi S., Adamchuk V., Ivanovs S., Pylypaka S. A theoretical study of the limit path of the movement of a layer of soil along the plough mouldboard. Soil \& Tillage Research, vol. 195, 2019, 104406

[12] Santoro F., Anifants A.S., Ruggiero G., Zavadskiy V., Pascuzzi S. Lightning Protection Systems Suitable for Stables: A Case Study. Agriculture Volume 9(4), 2019, 72 - DOI: 10.3390/agriculture9040072

[13] Pascuzzi S., Cerruto E., Manetto G. Foliar spray deposition in a "tendone" vineyard as affected by airflow rate, volume rate and vegetative development. Crop Protection, vol. 91,2017, pp. 34-48.

[14] Anifantis A.S. Performance assessment of photovoltaic, ground source heat pump and hydrogen heat generator in a stand-alone system for greenhouse heating. Chemical Engineering Transaction, vol. 58, 2017, pp. 511-516.

[15] Kraszkieicz A., Kachel M., Parfiniuk S., Zając G., Niedziółka I., Sprawka M. Assessment of the possibility of using hemp biomass (Cannabis sativa L.) for energy purposes: a case study. Appl. Sci.-Basel 2019 Vol. 9 Iss. 20 4437, DOI: 10.3390/app9204437

[16] Kraszkiewicz A., Stryjecka M., Nowosad N., Kocira S. Obciążenie środowiska produktami spalania peletów z biomasy roślinnej w kotle górnego spalania (Load the environment with combustion products of vegetable biomass pellets in the upper combustion boiler). Rocz. Ochr. Śr. 2018 T. 20 s. 1269-1285. (In Polish)

[17] Barmina I., Valdmanis R., Zake M., Wheat Straw Combustion and Co-firing for Clean Heat Energy Production, Chemical Engineering Transactions 2016, 52, pp. 919-924.

[18] Hardy T., Musialik-Piotrowska A., Ciołek J., Mościcki K., Kordylewski W. Negative effects of biomass combustion and co-combustion in boilers. Environment Protection Engineering 2012, Vol. 38, No. 1, pp. 25-33.

[19] Kubica K. Efektywne i przyjazne środowisku źródła ciepła - ograniczenie niskiej emisji Poradnik, Katowice 2010, pp. 1-45. http://www.office.fewe.pl/zasoby/poradniki/poradnik_niska \%20emisja.pdf

[20] Demirbas A. Combustion characteristics of different biomass fuels. Prog. Energy Combust Sci. 2004, Vol. 30, Issue 2, pp. 219-230.

[21] Jenkins B.M., Baxter L.L., Miles Jr. T.R., Miles T.R. Combustion properties of biomass. Fuel Processing Technology 1998, 54, pp. 17-46.

[22] Karcz H., Kantorek M., Grabowicz M., Wierzbicki K. Możliwość wykorzystania słomy jako źródła paliwowego w kotłach energetycznych (The possibility of using straw as a fuel source in power boilers). Piece przemysłowe i kotły 2013, Tom XI-XII, pp. 8-15. (In Polish)

[23] Pronobis M. Modernizacja kotłów energetycznych. WNT, Warszawa, 2013.

[24]EN ISO 17829:2016-02 - Solid biofuels - Determination of length and diameter of pellets.

[25]EN ISO 18134-3:2015 Solid biofuels - Determination of moisture content - Oven dry method Part 3: Moisture in general analysis sample.

[26]EN ISO 16948:2015 Solid biofuels - Determination of total content of carbon, hydrogen and nitrogen.

[27]EN ISO 16994:2016 Solid biofuels - Determination of total content of sulfur and chlorine.

[28]EN ISO 18123:2016 Solid biofuels - Determination of the content of volatile matter.

[29]EN ISO 18125:2017 Solid biofuels - Determination of calorific value.

[30]EN ISO 18122:2016 Solid biofuels - Determination of ash content.

[31] Górnicki K., Kaleta A., Jarosz A., Kosiorek K., Choińska A. Selected environmental factors and properties of the oat straw biomass. Ann. Warsaw Univ. Life Sci. - SGGW, Agricult. 2018, 71, 13-22. DOI 10.22630/AAFE.2018.71.2

[32]EN ISO 17225-1:2014 Solid biofuels - Fuel specifications and classes - part 1: General requirements.

[33] Juszczak M., Lossy K. 2012. Pollutant emission from a heat station supplied with agriculture biomass and wood pellet mixture. Chemical and Process Engineering, 33 (2), pp. 231-242. 